\title{
PENGEMBANGAN BUKU AJAR IPS-SEJARAH DIGITAL SMP
}

\author{
Syifaul Fuada ${ }^{1}$, Nainunis, A.I ${ }^{2}$, Aditya N.W. ${ }^{3}$ \\ ${ }^{1)}$ Sekolah Teknik Elektro dan Informatika Institut Teknologi Bandung \\ ${ }^{2)}$ Arkeologi Universitas Indonesia \\ ${ }^{3)}$ Sejarah Universitas Negeri Malang
}

\begin{abstract}
ABSTRAK
Inovasi dalam pembelajaran berperan membangkitkan motivasi belajar siswa. Di usia SMP siswa masih beradaptasi dari usia sekolah dasar, media pembelajaran dengan banyak aspek visual akan lebih membantu dibandingkan narasi teks saja. Buku ajar digital ini berisikan materi Sejarah SMP kelas VII yaitu materi masa praaksara, Hindu-Buddha, Islam, dan Kolonial. Media ini menggunakan software Adobe Flash Proffesional CS6, media ini berkonsep buku ajar digital yang interaktif dan estetik. Tujuan penelitian ini untuk menghasilkan buku sejarah digital berbasis animasi sebagai media belajar dan menguji kelayakan buku sejarah digital sebagai penunjang belajar siswa SMP kelas VII. Target penelitian ini berupa Artikel Ilmiah dengan produk berupa: (1) Media berupa produk akhir buku IPSsejarah digital dengan animasi flash. (2) Artikel Ilmiah hasil penelitian ini. Jenis penelitian adalah pengembangan, modelnya menggunakan langkah-langkah yang dikemukakan Sugiyono (2011: 298) yang dikolaborasikan dengan model pengembangan Pustekom Depdiknas. Produk ini layak dimanfaatkan dengan hasil validasi diatas $75 \%$ baik pada tahap validasi ahli, media, maupun uji coba produk. Validasi menggunakan metode angket dengan skala Likert dan diolah dengan teknik analisis rata-rata. Hasil analisis digunakan untuk menentukan kelayakan media. Diharapkan hasil penelitian ini dapat dikembangkan lebih lanjut dan dapat memenuhi kebutuhan siswa SMP kelas VII di masa depan.
\end{abstract}

Kata Kunci: buku ajar digital, pelajaran IPS-sejarah, PJJ, siswa SMP

\begin{abstract}
Innovation in learning plays a role in generating student learning motivation. In junior high school, students still adapt from elementary school age, learning media with many visual aspects will be more helpful than text narratives only. This digital textbook contains the History subject material of SMP class VII that is the material of pre-script, Hindu-Buddhist, Islam, and Colonial. This media uses Adobe Acrobat Flash Proffesional software, this medium conceptualized interactive and aesthetic digital textbooks. The purpose of this research is to produce digital history book based on animation as a learning media and to test the feasibility of digital history book as a supporter of student learning at SMP class VII. The target of this research is Scientific Article with products in the form of: (1) Media of end product IPS history digital book with flash animation. (2) Scientific article as the result of this study. The type of research is development, the model uses the steps proposed by Sugiyono (2011: 298) which collaborated with the Pustekom Depdiknas development model. This product is feasible to be utilized with validation result above $75 \%$ either in expert validation phase, media, or product trial. The validation process use the Likert-scale questionnaire method and processed by the mean analysis technique. The analysis results are used to determine the media feasibility. It is expected that the results of this study can be further developed and can meet the needs of SMP class VII students in the future.
\end{abstract}

Keywords: digital textbooks, social sciences studies-history, PJJ, junior high school students

DOI: $10.15408 /$ jti.v10i1.6969 


\section{PENDAHULUAN}

Mata pelajaran Sejarah dikenal dengan buku ajar yang berisikan banyak teks panjang. Materi yang kompleks dengan analisis fakta terkandung dalam teks-teks tersebut akan sulit untuk diterima anak-anak dalam periode sekolah menengah mengingat anak-anak lebih menyukai hal visual dibandingkan tekstual. Usia sekolah menengah merupakan usia dimana siswa masih beradaptasi dari usia sekolah dasar, sehingga dalam pembelajarannya tidak serta merta dijejali dengan kemampuan verbalistik namun yang lebih penting adalah kemudahan mencerna informasi melalui unsur visual [5]. Manfaat teoritis dari pemakaian media pembelajaran adalah untuk membangkitkan motivasi, rangsangan belajar, serta membawa pengaruh psikologis terhadap siswa. Pengaruh media pembelajaran akan sangat membantu keefektifan proses pembelajaran dan penyampaian isi pembelajaran sesuai tuntutan kurikulum. Hal tersebut didukung pula dengan aspek visual yang menurut hasil penelitian memberikan dampak lebih kuat daripada verbal [6].

Adobe Flash CS6 merupakan salah satu software untuk membuat animasi interaktif maupun non interaktif. Dan hingga kini, tenaga pendidik di sekolah-sekolah masih jarang menggunakan media pembelajaran berbasis animasi ini karena untuk mengoperasikannya perlu piranti komputer dan LCD Proyektor yang harganya relatif mahal. Animasi yang diterapkan dalam materi pembelajaran memberikan nilai lebih di mata siswa karena secara tampilan visual, animasi menampilkan gambar dan warna yang dipadukan secara komunikatif dengan materi pembelajaran. Hal ini didukung dari hasil penelitian yang mengungkapkan bahwa kemampuan menerima pesan yang paling tinggi adalah perpaduan indera pendengaran dan indera penglihatan [15]. Program-program yang diciptakan oleh software ini juga dapat di integrasikan kedalam berbagai device, misalnya saja Android untuk dioperasikan di Smartphone [8].

Buku ajar digital sejarah ini merupakan terobosan baru media pembelajaran dengan penggunaan animasi Adobe Flash CS6 untuk pokok bahasan sejarah, sehingga bukubuku teks sejarah tampil lebih komunikatif tanpa meninggalkan sisi edukasi. Adobe Flash Professional CS6 berguna untuk membuat Syifaul Fuada, dkk: Pengembangan Buku... animasi, baik animasi interaktif maupun animasi non interaktif. Melalui program Adobe Flash Proffesional CS6, user dapat membuat tombol interaktif dengan sebuah movie atau objek yang lain, dapat membuat perubahan transparasi warna dalam movie, dapat membuat perubahan animasi dengan mengikuti alur yang telah ditetapkan.

Kedekatan siswa terhadap teknologi menjadi sebuah peluang agar buku ajar digital sejarah ini dapat dengan mudah mereka gunakan. Buku ajar digital sejarah ini mengintegrasikan animasi serta ilustrasi sehingga mengangkat visualisasi dengan lebih optimal bila hanya dibandingkan dengan buku ajar. Buku digital yang akan dibuat ini dirancang untuk digunakan pada Kelas VII SMP pada mata pelajaran IPS khususnya materi sejarah. Buku digital ini diharapkan dapat menjadi media yang dapat membantu siswa belajar. Diharapkan buku sejarah ini dapat membuat informasi dalam pembelajaran menjadi lebih konkret. Menurut [11] semakin konkret siswa mempelajari maka semakin banyak pengalaman yang diperoleh siswa.

Buku ajar digital sejarah ini dirancang dengan konsep buku digital sehingga secara komunikatif mengajak siswa untuk memilih bagian-bagian pokok bahasan yang ingin diakses. Buku digital memiliki perwajahan seperti sebuah buku (dengan lembaran yang dapat dibolak-balik) dalam teknologi digital yang akan mempermudah siswa untuk membaca materi-materi sejarah karena dilayout dengan mempertimbangkan kemampuan baca siswa meski dalam bentuk buku non cetak. Selain itu terdapat animasi dengan tokoh icon dalam buku ajar digital sejarah ini sebagai teman belajar serta unsurunsur animasi lain yang berperan dalam menampilkan materi. Pemilihan setiap unsur dalam pelayoutan buku digital ini, baik warna, font, dokumentasi sejarah, gambar animasi serta komposisi tata letaknya mempertimbangkan aspek kelayakan estetika serta fungsional agar memberi kemudahan bagi siswa dalam menggunakannya sebagai media baca.

Pengembangan produk buku ajar digital sejarah ini diharapkan akan menjadi salah satu referensi media pembelajaran di sekolahsekolah dan sangat tepat guna meningkatkan kualitas pembelajaran jarak jauh. Pembelajaran jarak jauh adalah pendidikan yang peserta didiknya terpisah dari pendidik dan 
pembelajarannya menggunakan berbagai sumber belajar melalui teknologi komunikasi, informasi, dan media lain (Undang-Undang No 20 Tahun 2003). Dengan demikian, peserta didik seperti guru-guru yang ingin belajar dalam rangka meningkatkan kualifikasinya atau kompetensinya tidak perlu meninggalkan tugas mengajarnya, tetapi dapat belajar sambil mengajar.

Berdasarkan uraian di atas dapat diidentifikasi tujuan penelitian sebagai berikut, untuk (1) merancang Buku Sejarah Digital Berbasis Animasi Sebagai Penunjang Belajar Siswa SMP dan menguji kelayakan Buku Sejarah Digital Berbasis Animasi Sebagai Penunjang Belajar Siswa SMP. Artikel ini merupakan hasil orisinil dari penelitian yang para penulis telah lakukan.

\section{METODOLOGI}

\subsection{Jenis Penelitian}

Penulis menggunakan model Sugiyono [12], yang sudah disesuaikan sebagai metode untuk mengembangkan atau menghasilkan produk media pembelajaran. Pengembang memilih model pengembangan [12] karena pertimbangan sebagai berikut: (1) sifatnya sederhana dan terstruktur secara sistematis, menjadikan model ini mudah untuk dipelajari dan memudahkan pendesain meng-aplikasikan langkah-langkah dari model ini, (2) konsepnya yang sederhana tapi mewakili keseluruhan sistem proses pembelajaran, dan (3) strukturnya yang sistematis, sehingga tidak membingungkan pendesain dalam merancang sistem pembelajaran.

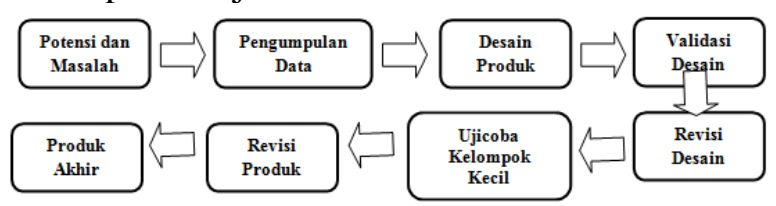

Gambar 1. Langkah-langkah Pengembangan Produk

\subsection{Prosedur Penelitian}

1. Potensi dan Masalah

Berdasarkan observasi, Mata pelajaran IPS-Sejarah dikenal dengan buku ajar yang berisikan banyak teks panjang. Materi yang kompleks dengan analisis fakta terkandung dalam teks-teks tersebut akan sulit untuk diterima anak-anak dalam periode sekolah menengah mengingat anak-anak lebih menyukai hal visual dibandingkan tekstual. Usia sekolah menengah merupakan usia dimana siswa masih beradaptasi dari usia sekolah dasar, sehingga dalam pembelajarannya tidak serta merta dijejali dengan kemampuan verbalistik namun yang lebih penting adalah kemudahan mencerna informasi melalui unsur visual.

\section{Pengumpulan Data}

Pengumpulan data dilakukan dengan model diskusi antar anggota dalam tim dan konsultasi pembimbing terkait penelitian pengembangan buku ajar sejarah digital. Sementara itu untuk menguji kelayakan Buku sejarah digital diperlukan observasi ke sekolah dan berkonsultasi dengan guru bidang studi IPS Terpadu untuk mengetahui secara langsung kondisi siswa, proses pembelajaran, sarana dan prasarana yang dimiliki sekolah tersebut. Dalam tahap ini peneliti melakukan bedah kurikulum dilakukan dengan melihat menelaah Silabus dari sekolah pada jenjang SMP. Berdasarkan studi, pada kurikulum 2013 ini.

\section{Desain Produk}

Produk berupa buku digital dengan konsep flip book terdapat animasi-animasi didalamnya untuk mewakili teks sehingga secara komunikatif mengajak siswa untuk memilih bagian-bagian pokok bahasan yang ingin diakses.

\section{Validasi Desain}

Validasi desain produk dilakukan oleh ahli materi/desain yang sudah berpengalaman untuk menilai desain produk yang akan dikembangkan dapat digunakan sebagai media pembelajaran yang efektif sehingga semua indikator pembelajaran dapat tercapai. Penulis menggunakan tiga acuan dalam penilaian media pembelajaran, yakni: Azhar Arsyad, Rayandra Asyhar, dan Romi Satrio Wahono [3].

\section{Revisi Desain}

Setelah desain media Buku Sejarah Digitalyang dikembangkan ini divalidasi oleh ahli materi/desain, jika terdapat beberapa kekurangan dalam mediatersebut kemudian kekurangan tersebut harus diperbaiki. 


\section{Uji -coba Kelompok Kecil}

Desain produk yang telah divalidasi oleh ahli media dan ahli materi dan direvisi siap untuk diujicobakan. Uji coba produk dilakukan kepada siswa SMP kelas VII yang sudah menempuh mata pelajaran sejarah, berjumlah 5 orang. Tujuan dari validasi ini untuk mengetahui bagaimanakah respon siswa selaku peserta didik atas pemanfaatan produk hasil penelitian.

\section{Revisi Produk}

Langkah selanjutnya setelah uji-coba produk selesei dan dianalisis, maka perlu dilakukan revisi pada buku ajar sejarah digitaluntuk menyempurnakan media pembelajaran. Media ajar diperbaiki sesuai dengan standarisasi yang diberikan.

\section{Produksi Akhir}

Setelah produk Buku Sejarah Digital direvisi maka langkah selanjutnya adalah memperbaikinya agar tercipta sebuah produksi akhir Buku Sejarah Digital yang siap digunakan sebagai salah satu media untuk inovasi dalam Mata Pelajaran IPS/Sejarah.

\subsection{Uji-coba Produk}

Uji coba produk dilakukan oleh ahli materi, ahli media dan siswa. Ahli materi dan ahli media sebagai subjek validasi. Sedangkan subjek uji-coba adalah siswa SMP kelas VII yang sudah menempuh pelajaran sejarah kelas VII.

\section{Desain Uji Coba}

Validasi yang digunakan adalah validasi deskriptif kualitatif dengan persentase. Hal ini dilakukan untuk menjelaskan kelayakan dari produk yang dihasilkan menggunakan persentase. Pelaksanaan uji kelayakan dilakukan dengan menyerahkan angket kepada ahli materi dan ahli media untuk melakukan penilaian dan memutuskan layak atau tidaknya media pembelajaran yang telah dibuat. Uji coba pemakaian dilakukan setelah ada keputusan dari ahli media dan ahli materi, jika keduanya memutuskan layak maka uji coba pemakaian dilakukan melalui uji coba kelompok kecil.

\section{Subjek Validasi dan Subjek Uji Coba}

Subjek validasi adalah validator yang melakukan validasi terhadap produk yang dikembangkan. Adapun spesifikasi validator disajikan pada Tabel 1.

Tabel 1. Spesifikasi Validator

\begin{tabular}{|c|c|c|c|c|}
\hline No. & Validator & Kriteria & Jumlah & $\begin{array}{c}\text { Bidang } \\
\text { Keahlian }\end{array}$ \\
\hline 1. & $\begin{array}{l}\text { Ahli } \\
\text { Media }\end{array}$ & - Dosen Sejarah (S2) & 1 Orang & - Media \\
\hline 2. & $\begin{array}{l}\text { Ahli } \\
\text { Materi }\end{array}$ & - Dosen Sejarah (S2) & 1 Orang & - Materi \\
\hline
\end{tabular}

Berdasarkan Tabel 1 maka telah dipilih oleh peneliti sebagai subjek validasi dalam penelitian ini, yakni: (1) Bapak Dewa Agung G.A sebagai ahli media dan (2) Bapak Kasimanudin Ismain sebagai ahli materi. Subjek pada uji coba ini merupakan sampel acak yang diambil dari seluruh SMP kelas VII yang sudah menempuh pelajaran sejarah kelas VII sebagai populasi.

\section{Jenis Data}

Jenis data yang terdapat dalam peneltian pengembangan merupakan data kualitatif dan kuantitatif.

\section{Instrumen Pengumpulan Data}

Instrumen yang digunakan untuk mengumpulkan data yaitu kuisioner/angket. Kuisioner yang digunakan adalah kuisioner tertutup, yakni kuisioner yang telah disediakan pilihan jawabanya sehingga responden tinggal memilih jawaban sesuai hanya dengan memberi tanda cek pada kolom-kolom jawaban yang telah disediakan (Check list). Pada penelitian ini instrumen yang digunakan untuk pengumpulan data dengan cara memberikan angket kepada validator (Pakar, Dosen), kemudian angket diberikan ke siswa sebagai subjek uji coba.

Tabel 2. Instrumen pengumpulan data Validator, Subjek Uji-coba

\begin{tabular}{|c|c|c|c|c|}
\hline \multirow[b]{2}{*}{ No } & \multirow[b]{2}{*}{$\begin{array}{l}\text { Subjek Uji } \\
\text { Coba }\end{array}$} & \multicolumn{2}{|c|}{ Jenis Data } & \multirow{2}{*}{$\begin{array}{c}\text { Instrumen } \\
\text { Pengumpulan Data }\end{array}$} \\
\hline & & $\begin{array}{c}\text { Data } \\
\text { Kuantitatif }\end{array}$ & $\begin{array}{c}\text { Data } \\
\text { Kualitatif }\end{array}$ & \\
\hline 1. & Ahli Media & $\sqrt{ }$ & $\sqrt{ }$ & Angket \\
\hline 2. & Ahli Materi & $\checkmark$ & $\sqrt{ }$ & Angket \\
\hline 3. & Responden & 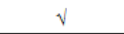 & $\sqrt{ }$ & Angket \\
\hline
\end{tabular}

[2] menyatakan bahwa sebelum menyusun angket ada beberapa prosedur yang harus dilalui yaitu:

a. Merumuskan tujuan yang akan dicapai dengan angket. Rumusan dari tujuan yang akan dicapai dalam angket ini adalah untuk mengetahui kelayakan media pembelajaran buku ajar sejarah digital. 
b. Mengidentifikasi variabel yang akan dijadikan sasaran angket. Variabel tersebut adalah tingkat kelayakan atau validitas media pembelajaran.

c. Menjabarkan setiap variabel menjadi sub variabel yang lebih spesifik dan tunggal (indikator atau sub indikator).

d. Menentukan jenis data yang akan dikumpulkan, sekaligus untuk menentukan teknik analisisnya. Jenis data yang dikumpulkan untuk dianalisis adalah data kuantitatif.

Dengan demikian, pada angket peneltian ini nantinya berisi pertanyaan tentang standar isi bahan ajar yang dinilai (validasi). Jenis angket yang disebarkan terdiri dari 2 jenis, yaitu: Angket untuk ahli media dan untuk ahli materi, untuk selanjutnya kedua angket tersebut diberikan kepada siswa. Produk yang divalidasi adalah buku ajar sejarah berbasis digital menggunakan animasi adobe flash.

\section{Teknik Analisis Data}

Setelah media pembelajaran selesai dibuat atau diproduksi maka akan dilakukan validasi kepada ahli media dan ahli materi. Validasi tersebut bertujuan untuk mengukur validitas atau kelayakan media pembelajaran sebelum diuji lapangan dengan menggunakan instrumen berupa angket. Adapun rumus yang digunakan untuk mengolah data dari ahli media dan ahli materi serta siswa sebagai pengguna berdasaarkan Sa'dun Akbar (2013:158) adalah,

1. Rumus untuk mengolah data ahli materi/media

$$
\mathrm{Va}=\frac{\mathrm{TSe}}{\mathrm{TSh}} \mathrm{x} 100 \%
$$

Keterangan :

$\begin{array}{lll}\text { Va } & \text { : Validitas dari ahli } \\ 100 \% & \text { : Kontanta } & \\ \text { TSh } & \text { : Total skor maksimal yang } \\ \text { diharapkan } & & \\ \text { TSe } & \text { : Total skor empiris } & \text { (hasil } \\ \text { validasi dari validator) } & \end{array}$

2. Rumus untuk mengolah data dari pengguna (siswa)

$$
\mathrm{Vp}=\frac{\mathrm{TSe}}{\mathrm{TSh}} \mathrm{x} 100 \%
$$

\author{
100\% : Kontanta \\ TSh : Total skor maksimal yang \\ diharapkan \\ TSe : Total skor empiris (hasil \\ validasi dari validator)
}

Buku ajar sejarah digital ini sudah dapat dimanfaatkan dalam proses belajar mengajar apabila sudah mencapai mencapai kriteria valid $(62,51 \%-81,25 \%)$ dan sangat valid (81,26\%-100\%). Pedoman dalam pengambilan keputusan dari analisis data menggunakan skala kualifikasi untuk menentukan kesimpulan dari apa yang telah tercapai.

\section{HASIL DAN PEMBAHASAN}

\section{Hasil Pengembangan Produk}

Hasil pada penelitian ini adalah digital book mengenai materi sejarah SMP Kelas VII yang mengacu pada kurikulum 2013. Digital book ini terdiri dari halaman utama (home), materi, evaluasi, bagian penutup, dan disertai dengan animasi gambar serta musik latar.

\section{A. Halaman Utama (Home)}

Halaman utama berisi cover dan link yang merujuk pada halaman lain.

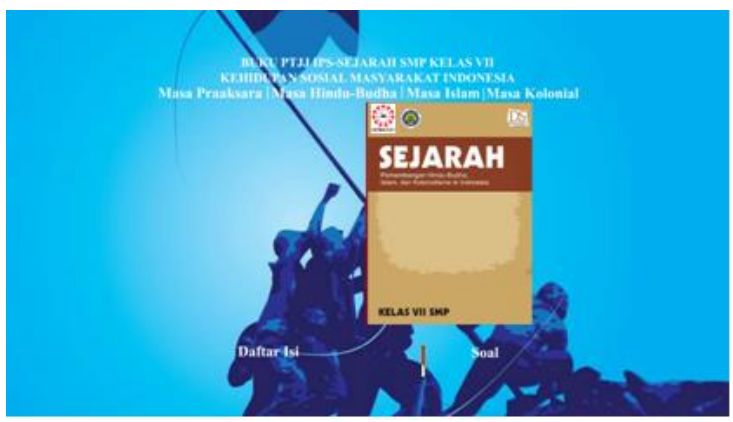

Gambar 2. Halaman Utama

\section{B. Halaman Depan}

Halaman Depan digital book terdiri dari pendahuluan, kegiatan belajar, dan penutup. Pendahuluan terdiri dari: (1) cover, (2) Petunjuk Penggunaan Buku, (3) Kompetensi Inti dan Kompetensi Dasar, (4) daftar isi. Cover berisi data bidang/program studi keahlian dan kompetensi keahlian, judul buku, gambar ilustrasi kesejarahan, dan logo lembaga yang terkait.

Keterangan :

Vp : Validitas dari pengguna

Syifaul Fuada, dkk: Pengembangan Buku... 


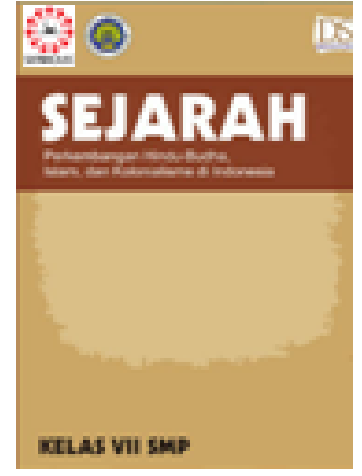

(a)

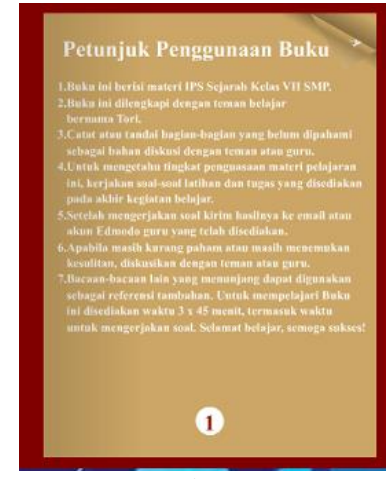

(b)

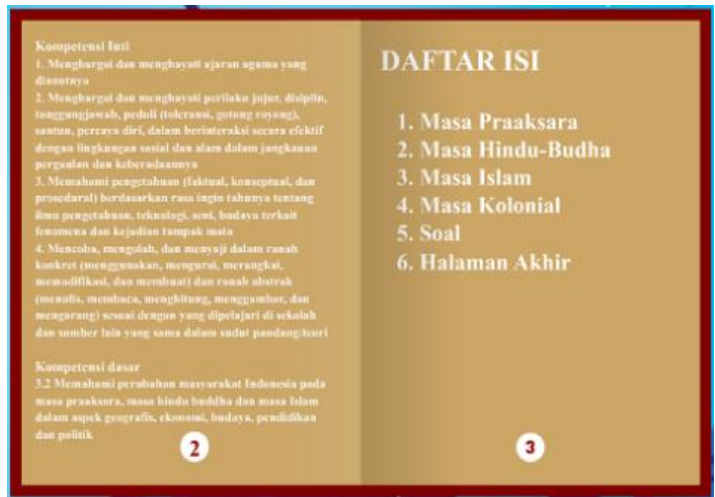

(c)

Gambar 3. Cover Buku (a), Petunjuk Penggunaan Buku (b), Kompetensi dan Daftar Isi (c)

\section{Materi}

Materi dalam Buku ini dibagi kedalam beberapa sub materi. Setian sub materi diawali dengan penyajian peta konsep dan di dalamnya terdapat animasi teks serta gambar yang akan memperjelas informasi dalam buku.

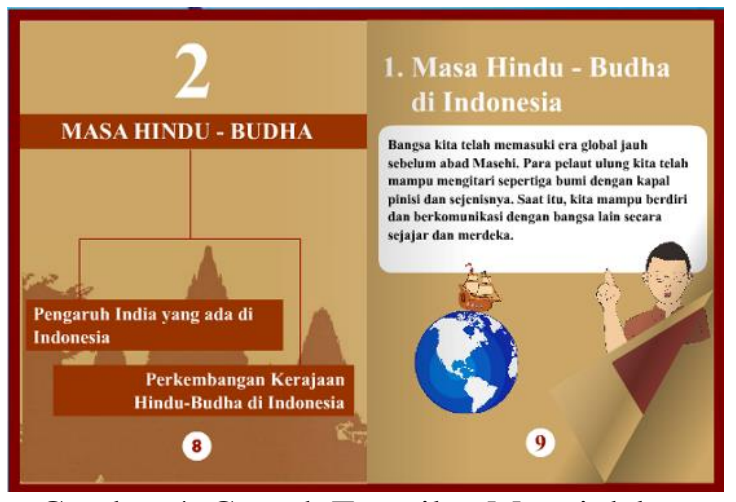

Gambar 4. Contoh Tampilan Materi dalam Buku Digital

\section{Evaluasi}

Melalui evaluasi yang bersifat dinamis ini, seorang siswa dapat mengetahui informasi tentang ujian yang diampu, melaksanakan ujian, mendapatkan nilai, serta mengevaluasi hasil belajar. Evaluasi dalam buku ini Syifaul Fuada, dkk: Pengembangan Buku... menggunaan bentuk soal pilihan ganda dimana setelah mengerjakan soal siswa langsung dapat melihat hasilnya yang dapat disimpan dalam bentuk dokumen.

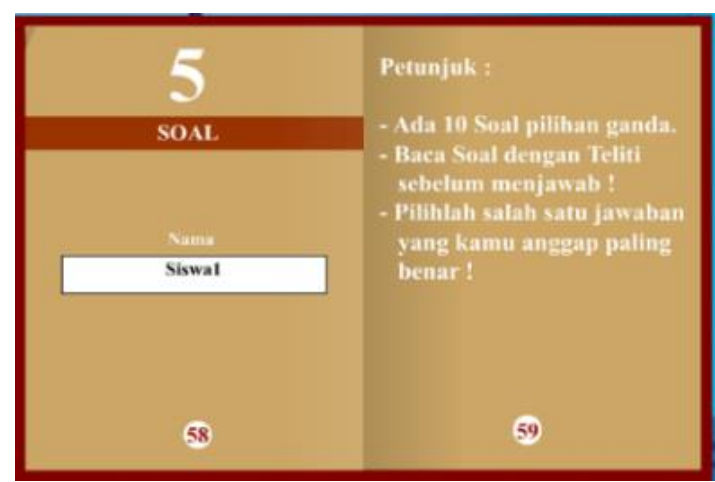

(a)

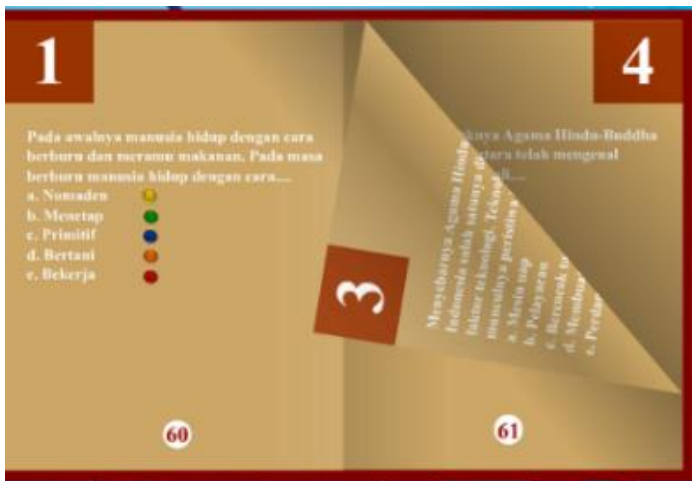

(b)

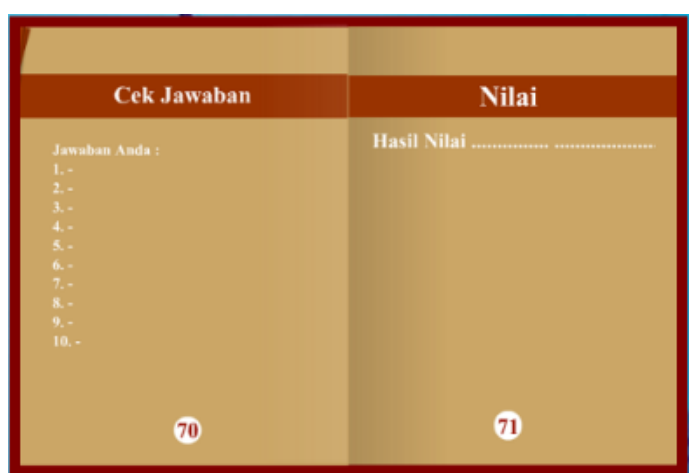

(c)

Gambar 5. Petunjuk Evaluasi (a), Soal (b), dan Hasil Evaluasi (c)

\section{E. Halaman Penutup}

Halaman ini menampilkan tim yang merancang produk pembelajaran ini. 


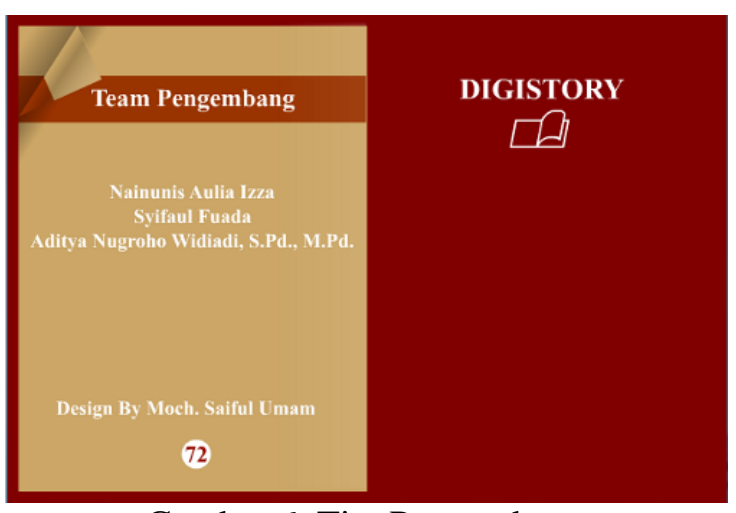

Gambar 6. Tim Pengembang

\section{Penyajian Data Uji Coba}

Berdasarkan metode pengembangan, produk diujikan kepada 2 (dua) validator, yaitu ahli media, ahli materi, dan subjek uji coba siswa kelompok kecil.

\section{a. Ahli Media}

Ahli media untuk validasi media pembelajaran yang dikembangkan ini adalah bapak Kasimanudin Ismain yakni dosen Sejarah, Fakultas Ilmu Sosial, Universitas Negeri Malang yang telah berpengalaman mengenai media pembelajaran berbasis animasi. Sehingga diharapkan mampu menilai kelayakan produk yang dihasilkan.

Validasi ahli media dilaksanakan pada hari Selasa tanggal 8 Juli 2014. Data yang dihimpun adalah data kualitatif yang berupa saran. Saran dan kritik yang diperoleh pada saat validasi ahli media dijadikan dasar untuk melakukan revisi sebelum media diujicobakan ke siswa. Validasi kepada ahli media menggunakan intrumen angket dengan 8 item pertanyaan, hasil validasi ahli media terdapat pada Lampiran 5.

Hasil validasi ahli media berdasarkan Lampiran 4 yakni, total skor TSe yang didapat yaitu 27. Nilai ideal untuk tiap-tiap skor yaitu 4, sehingga didapatkan TSh 32. Hubungan antara faktor-faktor tersebut digunakan untuk menghitung Validitas Ahli (Va) antara TSe terhadap TSh menggunakan persamaan 1 sebagai berikut:

$$
\begin{aligned}
\mathrm{Va} & =\frac{27}{32} \times 100 \% \\
\mathrm{Va} & =84,38 \%
\end{aligned}
$$

Dari pengolahan data keseluruhan butir soal diperoleh persentase $84,38 \%$ yang berarti media pembelajaran yang dikembangkan termasuk dalam kategori sangat valid dan layak untuk digunakan.

\section{b. Ahli Materi}

Ahli materi untuk validasi media pembelajaran yang dikembangkan ini adalah bapak Dewa Agung G.A. yakni dosen Sejarah, Fakultas Ilmu Sosial, Universitas Negeri Malang yang merupakan pengajar tentang materi-materi sejarah untuk siswa sekolah menengah pertama. Sehingga diharapkan mampu menilai kelayakan produk yang dihasilkan.

Validasi ahli materi dilaksanakan pada hari Selasa tanggal 8 Juli 2014. Saran dan kritik yang diperoleh pada saat validasi ahli media dijadikan dasar untuk melakukan revisi sebelum media diujicobakan ke siswa. Validasi kepada ahli materi menggunakan intrumen angket dengan 20 item pertanyaan, hasil validasi ahli materi terdapat pada Lampiran 4.

Hasil validasi ahli materi berdasarkan lampiran 4 yakni, total skor TSe yang didapat yaitu 72 . Nilai ideal untuk tiap-tiap skor yaitu 4, sehingga didapatkan TSh 80. Hubungan antara faktor-faktor tersebut digunakan untuk menghitung Validitas Ahli (Va) antara TSe terhadap TSh menggunakan persamaan 1 sebagai berikut:

$$
\begin{aligned}
\mathrm{Va} & =\frac{72}{80} \times 100 \% \\
\mathrm{Va} & =90 \%
\end{aligned}
$$

Dari pengolahan data keseluruhan butir soal diperoleh persentase $90,0 \%$ yang berarti media pembelajaran yang dikembangkan termasuk dalam kategori sangat valid dan layak untuk digunakan.

\section{c. Uji Coba Kelompok Kecil}

Setelah media direvisi berdasarkan saran dan kritik dari ahli media dan ahli materi, maka langkah selanjutnya adalah media diujicobakan ke peserta didik untuk kelompok kecil. Uji coba peserta didik ini dilakukan pada siswa SMP kelas VII SMPN Bungul, Kec. Kujang, Kab. Kediri, Jawa Timur yang telah menempuh mata pelajaran SMP untuk materi dasar sebanyak 5 (lima) orang dan dilaksanakan pada hari Minggu tanggal 27 Juli 2014 terselenggara di rumah salah satu anggota peneliti SEAMOLEC ini. Uji coba kepada peserta didik menggunakan intrumen angket dengan 15 item pertanyaan. 
Data uji coba dapat dilihat pada Lampiran 6, TSe-1 menyatakan jumlah skor siswa pertama, TSe-2 menyatakan skor dari siswa kedua, hingga TSe-5 menyatakan siswa kelima. TSe menyatakan jumlah skor untuk semua siswa. TSh menyatakan jumlah skor ideal untuk semua siswa.

Berdasarkan penjumlahan skor TSe didapatkan 278. Nilai ideal untuk tiap-tiap skor yaitu 4, sehingga didapatkan TSh sebesar 300 . Hubungan antara faktor-faktor tersebut digunakan untuk menghitung Validitas Pengguna $(\mathrm{Vp})$ antara TSe terhadap TSh menggunakan persamaan 2 sebagai berikut:

$$
\begin{aligned}
& \mathrm{Vp}=\frac{278}{300} \times 100 \% \\
& \mathrm{Vp}=92,67 \%
\end{aligned}
$$

Dari pengolahan data keseluruhan butir soal diperoleh persentase $92,67 \%$ yang berarti media pembelajaran yang dikembangkan termasuk dalam kategori valid dan layak untuk digunakan.

Berdasarkan hasil validasi dari ahli media, ahli materi dan uji coba lapangan maka didapatkan data akhir sebesar 84,38\% untuk ahli media, 90,00\% untuk ahli materi, 92,67\% untuk ujicoba kelompok kecil.

\section{Revisi Produk}

Revisi produk merupakan catatan revisi yang diberikan oleh validator saat menilai media dan siswa saat memberikan tanggapan tentang media. Revisi produk ini digunakan sebagai acuan untuk memperbaiki kekurangankerurangan media sehingga menjadi lebih baik.

\section{PENUTUP}

\subsection{Kesimpulan}

Materi pembelajaran merupakan salah satu hal yang terpenting dalam proses belajar dna mengajar. Bahkan, dalam pengajaran yang terpusat pada materi pelejaran materi merupakan inti dari kegiatan pembelajaran [11]. Jadi, dalam penelitian ini penulis memilih materi Hindu-Buddha, Islam, dan Kolonial sebagai bahan karena menurut penulis materi ini memiliki rentang waktu yang cukup lama, sehingga siswa sering kesulitan untuk memahami rekonstruksi sejarah masa itu, dan materi ini dapat menampilkan animasi-animasi yang menakjubkan. Media pembelajaran Digistory ini memenuhi kriteria layak dan valid untuk digunakan, setelah melalui proses validasi, uji coba dan proses revisi yang dilakukan oleh para ahli, diantaranya sebagai berikut:

a. Instrumen ahli media divalidasi oleh bapak Kasimanudin Ismain, pada hari Selasa tanggal 8 Juli 2014, diperoleh nilai validasi sebesar $84,38 \%$ (sangat valid).

b. Instrumen ahli materi divalidasi oleh bapak Dewa Agung G.A, pada hari Selasa tanggal 8 Juli 2014, diperoleh nilai validasi sebesar 90,0\% (sangat valid).

c. Instrumen uji coba subjek kelompok kecil pada hariMinggu tanggal 27 Juli 2014, dengan subjek coba yang berasal darisiswa SMP kelas VII SMPN Bungul, Kec. Kujang, Kab. Kediri, Jawa Timur yang telah menempuh mata pelajaran SMP untuk materi dasar sebanyak 5 (lima) orang, diperoleh data keseluruhan dengan total 92,67\% (sangat valid).

Digistory merupakan sebuah media pembelajaran berbentuk buku sejarah digital yang memungkinkan adanya teks, gambar, video, dan animasi dalam sebuah tayangan. Diharapkan hasil penelitian ini dapat diimplementasikan dan menyelesaikan masalah dalam dunia pendidikan khususnya dalam mata pelajaran sejarah baik di jenjang skolah dasar maupun menengah.

\subsection{Saran}

Agar produk yang dihasilkan dapat dimanfaatkan secara maksimal, terdapat empat ranah saran yang perlu diperhatikan, yaitu: saran validator, saran pemanfaatan, saran deseminasi produk pada sasaran yang lebih luas, dan saran pengembangan produk lebih lanjut.

Saran validator yaitu perlu adanya video/suara agar siswa tidak merasa bosan, perlu adanya glosarium, intermezzo, kesimpulan, latihan, dan evaluasi agar siswa dapat lebih tertarik menggunakan buku ajar dengan media yang berbeda dan menarik. Adapun saran pemanfaatannya ialah sebaiknya guru menerapkan teori belajar konstruktifisme di kelas agar siswa lebih aktif mengkonstruksi pengetahuan dan pemahaman materi, model pembelajaran yang digunakan sebaiknya adalah Contextual Teaching and Learning (CTL) agar siswa dapat memaknai pengetahuan berdasarkan pengalaman belajar mereka, serta metode pembelajaran yang 
digunakan sebaiknya adalah metode drill and practice agar kemampuan siswa lebih terasah.

Saran deseminasi produk pada sasaran yang lebih luas yaitu buku dapat digunakan jika komputer pada laboratorium sekolah telah terinstal Adobe, sedangkan saran pengembangan produk lebih lanjut, yakni media pembelajaran yang dikembangkan memiliki berbagai macam perangkat yang dapat digunakan untuk memaksimalkan penggunaan media pembelajaran. Perangkat tersebut seperti animasi flash, jenis soal yang berfariasi (pilihan ganda, isian, mencocokan, lebih dari satu jawaban benar), pengumpulan tugas secara langsung melalui media pembelajaran, dan laporan kemajuan belajar, media pembelajaran yang dikembangkan masih berfokus pada materi IPS Sejarah SMP kelas VII.

Untuk pengembangan lebih lanjut dapat mengembangkan media dengan materi kelas VIII ataupun kelas IX, dikarenakan persentase kelayakan buku belum mencapai $100 \%$. Keakuratan tingkat kelayakan ini juga masih dapat ditingkatkan dengan memperbanyak validasi kepada ahli media, ahli ahli materi, dan siswa.

\section{DAFTAR PUSTAKA}

[1] Akbar, Sa'dun. 2013. Instrumen Perangkat Pembelajaran. Bandung: PT Remaja Rosdakarya.

[2] Arikunto, S. 2010. Prosedur Penelitian Suatu Pendekatan Praktik (Edisi Revisi 2010). Jakarta: PT Rineka Cipta.

[3] Arsyad, A, dkk. (2011) Media Pembelajaran. Jakarta: Rajawali Pers.

[4] Asyhar, R. 2012. Kreatif Mengembangkan Media Pembelajaran. Jakarta: Referensi Jakarta.

[5] Fuada, dkk 2013. Digistory: History Books For Indonesia Future.

[6] Hariyono. 1995. Mempelajari Sejarah Secara Efektif. Jakarta: Pustaka Jaya.

[7] Kumar, dkk. 2013. Developing Mobile Applications Using Android. Proceeding International Seminar on Electrical, Information and It's Education. Malang, October $5^{\text {th }}, 2013$.

[8] Sanjaya. 2012. Perencanaan dan Desain Sistem Pembelajaran. Jakarta: Kencana Prenada Media Grup.
[9] Sugiyono. 2011. Metode Penelitian Kuantitatif, Kualitatif dan $R \& D$. Bandung: Alfabeta Bandung. Hal. 297.

[10] Undang-undang Republik Indonesia Nomor 20 Tahun 2003 tentang Sistem Pendidikan Nasional. 2004. Jakarta.

[11] Wahono, R.S. 2006. Aspek dan Kriteria Penilaian Media Pembelajaran, (Online), (http://romisatriawahono.net/2006/06/21 laspek-dan-kriteria-penilaian-mediapembelajaran/) diakses pada 14 Mei 2013.

[12] Xiao, L. 2013. Animation Trends in Education. International Journal of Information and Education Technology, Vol. 3, No. 3, June 2013. PP 286 - 288. 


\section{Lampiran 4. Hasil validasi ahli materi}

\begin{tabular}{|c|c|c|c|c|c|}
\hline No & Pernyataan & $\begin{array}{c}\text { Skor } \\
\text { TSe } \\
1\end{array}$ & TSh & $\begin{array}{c}\text { Persentase } \\
\%\end{array}$ & Kriteria \\
\hline 1 & Bahan ajar mudah digunakan & 4 & 4 & $100 \%$ & Sangat Valid \\
\hline 2 & $\begin{array}{l}\text { Bahan ajar dapat digunakan untuk belajar } \\
\text { mandiri }\end{array}$ & 4 & 4 & $100 \%$ & Sangat Valid \\
\hline 3 & Tujuan sesuai dengan silabus & 4 & 4 & $100 \%$ & Sangat Valid \\
\hline 4 & Materi sesuai dengan tujuan pembelajaran & 4 & 4 & $100 \%$ & Sangat Valid \\
\hline 5 & Ketepatan Judul bab dengan isi materi & 3 & 4 & $75 \%$ & Valid \\
\hline 6 & Materi disusun sistematis & 3 & 4 & $75 \%$ & Valid \\
\hline 7 & $\begin{array}{l}\text { Petunjuk penggunaan bahan ajar sudah } \\
\text { ditampilkan }\end{array}$ & 4 & 4 & $100 \%$ & Sangat Valid \\
\hline 8 & Daftar isi ditampilkan secara jelas & 4 & 4 & $100 \%$ & Sangat Valid \\
\hline 9 & $\begin{array}{l}\text { Materi sesuai dengan tingkat pemahaman } \\
\text { siswa SMP }\end{array}$ & 3 & 4 & $75 \%$ & Valid \\
\hline 10 & Penyajian gambar sesuai dengan isi materi & 4 & 4 & $100 \%$ & Sangat Valid \\
\hline 11 & Komposisi warna tepat & 3 & 4 & $75 \%$ & Valid \\
\hline 12 & Soal mudah dipahami siswa & 4 & 4 & $100 \%$ & Sangat Valid \\
\hline 13 & Soal sesuai dengan tujuan pembelajaran & 4 & 4 & $100 \%$ & Sangat Valid \\
\hline 14 & Kualitas audio dan video bagus & 3 & 4 & $75 \%$ & Valid \\
\hline 15 & Teks dalam bahan ajar terbaca dengan jelas & 4 & 4 & $100 \%$ & Sangat Valid \\
\hline 16 & Animasi disajikan secara interaktif & 3 & 4 & $75 \%$ & Valid \\
\hline 17 & $\begin{array}{l}\text { Tombol navigasi mempermudah } \\
\text { penggunaan }\end{array}$ & 4 & 4 & $100 \%$ & Sangat Valid \\
\hline 18 & Penggunaan bahasa komunikatif & 4 & 4 & $75 \%$ & Sangat Valid \\
\hline 19 & Font yang dipilih tepat & 3 & 4 & $75 \%$ & Valid \\
\hline 20 & $\begin{array}{l}\text { Secara keseluruhan bahan ajar dapat } \\
\text { digunakan sebagai sarana pembelajaran }\end{array}$ & 4 & 4 & $100 \%$ & Sangat Valid \\
\hline Total & & 72 & 80 & $90 \%$ & Sangat Valid \\
\hline
\end{tabular}




\section{Lampiran 5. Hasil validasi ahli media}

\begin{tabular}{clcccc}
\hline \hline No & Pernyataan & $\begin{array}{c}\text { Skor } \\
\text { TSe } \\
1\end{array}$ & TSh & Persentase & Kriteria \\
\hline 1 & Kerapihan media & 4 & 4 & $100 \%$ & Sangat Valid \\
\hline 2 & Media bersih dan menarik & 4 & 4 & $100 \%$ & Sangat Valid \\
\hline 3 & $\begin{array}{l}\text { Media cocok dengan sasaran yaitu siswa } \\
\text { Kelas VII SMP }\end{array}$ & 4 & 4 & $100 \%$ & Sangat Valid \\
\hline 4 & $\begin{array}{l}\text { Media sesuai dengan kemampuan siswa } \\
\text { Kelas VII SMP }\end{array}$ & 4 & 4 & $100 \%$ & Sangat Valid \\
\hline 5 & $\begin{array}{l}\text { Media memenuhi ranah kognitif, afektif, } \\
\text { psikomotorik }\end{array}$ & 2 & 4 & $50 \%$ & Valid \\
\hline 6 & Media praktis, luwes, dan tahan lama & 3 & 4 & $75 \%$ & Valid \\
\hline 7 & $\begin{array}{l}\text { Kriteria teknis dalam media berkualitas } \\
\text { baik }\end{array}$ & 3 & 4 & $75 \%$ & Valid \\
\hline 8 & $\begin{array}{l}\text { Media dibuat sesuai dengan ukuran } \\
\text { lingkungan belajar }\end{array}$ & 3 & 4 & $\mathbf{7 5 \%}$ & Valid \\
\hline Total & & $\mathbf{2 7}$ & $\mathbf{3 2}$ & $\mathbf{8 4 . 3 7 5 \%}$ & Sangat Valid \\
\hline \hline
\end{tabular}




\section{Lampiran 6. Hasil uji coba siswa kelompok kecil}

\begin{tabular}{|c|c|c|c|c|c|c|c|c|c|c|}
\hline \multirow{3}{*}{ No } & \multirow{3}{*}{ Pernyataan } & \multirow{2}{*}{\multicolumn{5}{|c|}{$\begin{array}{c}\text { Skor } \\
T S e\end{array}$}} & \multirow{3}{*}{$\begin{array}{l}\text { Skor } \\
\text { TSe }\end{array}$} & \multirow{3}{*}{ TSh } & \multirow{3}{*}{$\begin{array}{c}\text { Persentase } \\
\%\end{array}$} & \multirow{3}{*}{ Kriteria } \\
\hline & & & & & & & & & & \\
\hline & & 1 & 2 & 3 & 4 & 5 & & & & \\
\hline 1 & $\begin{array}{l}\text { Media pembelajaran } \\
\text { DIGISTORY mudah saya } \\
\text { gunakan }\end{array}$ & 3 & 4 & 4 & 3 & 4 & 18 & 20 & $90 \%$ & $\begin{array}{c}\text { Sangat } \\
\text { Valid }\end{array}$ \\
\hline 2 & $\begin{array}{l}\text { Saya kira saya dapat belajar } \\
\text { banyak dari media pembelajaran } \\
\text { DIGISTORY ini }\end{array}$ & 4 & 3 & 4 & 3 & 3 & 17 & 20 & $85 \%$ & $\begin{array}{l}\text { Sangat } \\
\text { Valid }\end{array}$ \\
\hline 3 & $\begin{array}{l}\text { Media pembelajaran } \\
\text { DIGISTORY menarik sehingga } \\
\text { dapat menumbuhkan motivasi } \\
\text { belajar saya }\end{array}$ & 4 & 3 & 4 & 3 & 3 & 17 & 20 & $85 \%$ & $\begin{array}{l}\text { Sangat } \\
\text { Valid }\end{array}$ \\
\hline 4 & $\begin{array}{l}\text { Media Pembelajaran } \\
\text { DIGISTORY dapat saya } \\
\text { gunakan untuk belajar mandiri }\end{array}$ & 4 & 3 & 4 & 3 & 4 & 18 & 20 & $90 \%$ & $\begin{array}{c}\text { Sangat } \\
\text { Valid }\end{array}$ \\
\hline 5 & $\begin{array}{l}\text { Tombol navigasi memudahkan } \\
\text { saya untuk mencari materi yang } \\
\text { akan saya pelajari }\end{array}$ & 4 & 4 & 4 & 3 & 4 & 19 & 20 & $95 \%$ & $\begin{array}{c}\text { Sangat } \\
\text { Valid }\end{array}$ \\
\hline 6 & $\begin{array}{l}\text { Saya lebih senang belajar dari } \\
\text { media pembelajaran } \\
\text { DIGISTORY dari pada membaca } \\
\text { buku teks pelajaran sejarah }\end{array}$ & 4 & 4 & 4 & 3 & 4 & 19 & 20 & $95 \%$ & $\begin{array}{l}\text { Sangat } \\
\text { Valid }\end{array}$ \\
\hline 7 & $\begin{array}{l}\text { Materi pada Media Pembelajaran } \\
\text { DIGISTORY ini mudah saya } \\
\text { pahami }\end{array}$ & 4 & 2 & 4 & 3 & 4 & 17 & 20 & $85 \%$ & $\begin{array}{l}\text { Sangat } \\
\text { Valid }\end{array}$ \\
\hline 8 & $\begin{array}{l}\text { Gambar pada Media } \\
\text { Pembelajaran DIGISTORY } \\
\text { menarik }\end{array}$ & 4 & 3 & 4 & 4 & 4 & 19 & 20 & $95 \%$ & $\begin{array}{l}\text { Sangat } \\
\text { Valid }\end{array}$ \\
\hline 9 & $\begin{array}{l}\text { Warna pada Media Pembelajaran } \\
\text { DIGISTORY menarik }\end{array}$ & 3 & 4 & 4 & 4 & 4 & 19 & 20 & $95 \%$ & $\begin{array}{c}\text { Sangat } \\
\text { Valid }\end{array}$ \\
\hline 10 & $\begin{array}{l}\text { Soal latihan mudah saya pahami } \\
\text { dan tidak membingungkan }\end{array}$ & 4 & 4 & 4 & 4 & 4 & 20 & 20 & $100 \%$ & $\begin{array}{c}\text { Sangat } \\
\text { Valid }\end{array}$ \\
\hline 11 & $\begin{array}{l}\text { Ukuran Media Pembelajaran } \\
\text { DIGISTORY menurut saya } \\
\text { sudah tepat (tidak terlalu kecil } \\
\text { ataupun terlalu besar) }\end{array}$ & 4 & 3 & 4 & 4 & 4 & 19 & 20 & $95 \%$ & $\begin{array}{l}\text { Sangat } \\
\text { Valid }\end{array}$ \\
\hline 12 & $\begin{array}{l}\text { Audio dan video pada Media } \\
\text { Pembelajaran DIGISTORY } \\
\text { menurut saya bagus }\end{array}$ & 4 & 4 & 3 & 4 & 4 & 19 & 20 & $95 \%$ & $\begin{array}{c}\text { Sangat } \\
\text { Valid }\end{array}$ \\
\hline 13 & $\begin{array}{l}\text { Teks dalam Media Pembelajaran } \\
\text { DIGISTORY dapat saya baca } \\
\text { dengan jelas }\end{array}$ & 4 & 4 & 3 & 3 & 4 & 18 & 20 & $90 \%$ & $\begin{array}{l}\text { Sangat } \\
\text { Valid }\end{array}$ \\
\hline 14 & $\begin{array}{l}\text { Animasi pada Media } \\
\text { Pembelajaran DIGISTORY } \\
\text { menarik }\end{array}$ & 4 & 4 & 4 & 3 & 4 & 19 & 20 & $95 \%$ & $\begin{array}{c}\text { Sangat } \\
\text { Valid }\end{array}$ \\
\hline 15 & $\begin{array}{l}\text { Secara keseluruhan Media } \\
\text { Pembelajaran DIGISTORY } \\
\text { menurut saya menarik dan asyik } \\
\text { untuk dipelajari }\end{array}$ & 4 & 4 & 4 & 4 & 4 & 20 & 20 & $100 \%$ & $\begin{array}{l}\text { Sangat } \\
\text { Valid }\end{array}$ \\
\hline Total & & 58 & 53 & 58 & 51 & 58 & 278 & 300 & $93 \%$ & $\begin{array}{l}\text { Sangat } \\
\text { Valid }\end{array}$ \\
\hline
\end{tabular}

